\title{
FAKTOR-FAKTOR YANG BERHUBUNGAN DENGAN KEJADIAN KANKER SERVIKS DI RSUP DR M.DJAMIL PADANG TAHUN 2017
}

\author{
Mega Wanda ${ }^{1}$, Nike Sari Oktavia ${ }^{2}$, Elda Yusefni ${ }^{3}$ \\ Politeknik Kesehatan Kemenkes Padang, Prodi DIV Kebidanan Padang \\ Jl. Simpang Pondok Kopi Nanggalo, 25416, Indonesia \\ Email :wandamega18@gmail.com
}

\begin{abstract}
ABSTRAK
Kanker serviks merupakan salah satu penyebab kematian terbanyak, estimasi jumlah kanker serviks di Indonesia sebanyak 98.692 kasus. Estimasi jumlah kanker serviks di Sumatera Barat sebanyak 2.285 kasus. Jumlah penderita kanker serviksdi RSUP DR M.Djamil Padang meningkat dari tahun 2014 sampai 2015 dengan peningkatan sebanyak 44\%. Tujuan penelitian ini untuk mengetahui faktor-faktor yang berhubungan dengan kejadian kanker serviks di RSUP DR M.Djamil Padang tahun 2017.

Metode penelitian ini deskriptif analitik dengan menggunakan pendekatan cross sectional. Pengumpulan data dilakukan tanggal 15 Desember 2016 - 15 Januari 2017 di ruangan Ginekologi RSUP DR M.Djamil Padang, dengan besar sampel 80 orang. Sampel ini diambil secara Non Random Sampling dengan teknik total populasi. Data dikumpulkan menggunakan kuisioner. Analisis data terdiri dari analisis univariat dan bivariat yang diolah dengan uji Chi-Square.

Hasil penelitian didapatkan 37,5\% pasien menderita kanker serviks, $60 \%$ pasien melakukan intercourse pada usia muda $(<$ 20 tahun), 33,8\% pasien memiliki paritas tinggi (> 3), 36,2\% pasien memakai kontrasepsi hormonal dalam waktu $\geq 5$ tahun. Hasil analisis bivariat terdapat hubungan usia pertama melakukan intercourse dengan kejadian kanker serviks $(0,010)$, tidak ada hubungan paritas dengan kejadian kanker serviks $(0,246)$, ada hubungan pemakaian kontrassepsi hormonal dengan kejadian kanker serviks $(0,003)$.

Disimpulkan adanya hubungan usia pertama melakukan intercourse, pemakaian kontrasepsi hormonal dengan kejadian kanker serviks dan tidak ada hubungan paritas dengan kejadian kanker serviks. Diharapkan kepada masyarakat agar mengurangi lama pemakaian kontrasepsi hormonal dengan memakai kontrasespi non hormonal dan tidak melakukan intercourse pada usia muda.
\end{abstract}

Kata kunci : usia pertama melakukan intercourse, paritas, pemakaian kontrasepsi hormonal, kanker serviks

\begin{abstract}
Cervical cancer is one cause of death most, estimation the number of servical cancer in Indonesia as many as 98.692 cases. Estimation the number of servical cancer in West Sumatera as many as 2.285 cases. The number of cervical cancer In Hospital DR M.Djamil Padang increased from 2014 to 2015 with an increase of 44\%. The purpose of this study to determine the factors associated with the incidence of cervical cancer in DR M.Djamil Padang on 2017.

Methods this study was descriptive analytic with approach cross sectional The data collection was done on December $15^{\text {th }}$, 2016 - January 15 th 2017 in room Gynecology DR M.Djamil Padang, with a sample size of 80 respondents. These samples were taken in Non-Random Sampling technique the total population. Data were collected using a questionnaire. The data analysis consisted of univariate and bivariate analysis were prepared by Chi-Square.

The results showed $37.5 \%$ of patients with cervical cancer, $60 \%$ of patients to perform intercourse at a young age $(<20$ years), $33.8 \%$ of patients had high parity (> 3), 36.2\% of patients taking hormonal contraception within $\geq 5$ years. The results of the bivariate correlation analysis of the age of first intercourse with the incidence of cervical cancer $(0,010)$, no parity correlation with the incidence of cervical cancer (0.246), there is correlation use of hormonal contraception with incidence of cervical cancer (0,003).

Concluded therearecorrelation age of first intercourse, use of hormonal contraception with cervical cancer incidence and no parity correlation with the incidence of cervical cancer.Expected to the public to reduce the duration of use hormonal contraception by using non hormonal contraception and didn't do intercourse at a young age.
\end{abstract}

Keywords : age at first intercourse, parity, use of hormonal contraception, cervical cancer 


\section{PENDAHULUAN}

Kanker merupakan salah satu penyebab utama kematian di seluruh dunia, salah satunya yaitu kanker serviks yang merupakan penyebab kematian terbanyak terutama di negara berkembang. Kanker serviks disebabkan oleh infeksi human Pappiloma Virus (hPV) yang merangsang perubahan perilaku sel epitel serviks. ${ }^{1,2}$

Berdasarkan data International Agency for Research on Cancer (IARC) diketahui bahwa pada tahun 2012 terdapat 14.067.894 kasus baru kanker dan 8.201.575 kematian akibat kanker di seluruh dunia. Hal tersebut menunjukkan bahwa lebih dari setengah penderita kanker yang meninggal dunia. ${ }^{1}$

Berdasarkan Riset Kesehatan Dasar (riskesdas) yang dilaksanakan oleh Badan Penelitian dan Pengembangan Kesehatan Kementerian Kesehatan RI tahun 2013 didapatkan prevalensi penderita kanker pada penduduk semua umur di Indonesia sebesar 1,4\% (perseribu). Provinsi Sumatera Barat menunjukkan angka yang sedikit lebih tinggi dari angka prevalensi nasional yaitu sebesar $1,7 \% \%^{3}$

Berdasarkan data rutin Subdit Kanker Direktorat Penyakit Tidak Menular, Direktorat Jenderal Pengendalian Penyakit dan Penyehatan Lingkungan Kementerian Kesehatan RI sampai dengan tahun 2013 estimasi jumlah kanker serviks di Indonesia sebanyak 98.692 kasus. Estimasi jumlah kanker serviks di Sumatera Barat sebanyak 2.285 kasus. $^{3}$

Jumlah penderita kanker serviks di RSUP DR M.Djamil Padang pada tahun 2014 sebanyak 140 kasus dan pada tahun 2015 sebanyak 201 kasus, terjadi peningkatan kejadian kanker serviks yaitu sebanyak 61 kasus (44\%). Pada bulan Januari Juli 2016 jumlah pasien kanker serviks yang dirawat di ruang ginekologi kebidanan yaitu sebanyak 107 orang. ${ }^{4}$ Berdasarkan hasil studi pendahuluan yang dilakukan di ruangan ginekologi RSUP DR M.Djamil Padang diketahui bahwa dari 6 orang pasien kanker serviks 4 orang melakukan intercourse pada usia muda, 5 orang yang melahirkan $\geq 3$ kali dan 5 orang yang memakai kontrasepsi. ${ }^{4}$

Faktor risiko yang berhubungan dengan kanker serviks yaitu melakukan intercourse pada usia muda, paritas, pemakaian kontrasepsi hormonal. Berdasarkan penelitian yang dilakukan di Rwanda yang merupakan salah satu negara di Afrika Timur pada tahun 2010-2013 diperoleh hasil bahwa responden yang melakukan hubungan seksual usia $<20$ tahun berisiko 1,75 kali dari pada yang melakukan hubungan seksual pada usia $\geq 20$ tahun. ${ }^{1,5,67}$

Berdasarkan penelitian yang dilakukan oleh Hidayat pada tahun 2013 yang berjudul hubungan kejadian kanker serviks dengan jumlah paritas di RSUD Dr.Moewardi tahun 2013 didapatkan hasil bahwa dari 41 responden yang menderita kanker serviks $26(63,4 \%)$ responden diantaranya memiliki paritas > 3 atau berisiko 16,03 kali terkena kanker serviks daripada responden yang memiliki jumlah paritas $<3 .{ }^{8}$

Terdapat 880.704 pasangan usia subur yang diantaranya 154.062 orang peserta KB baru dan sebanyak 536.447 orang peserta KB aktif. Pemakaian kontrasepsi hormonal oleh peserta $\mathrm{Kb}$ aktif dan baru yaitu sebanyak 568.047 dan kontrasepsi non hormonal sebanyak 122.375. Angka tersebut menunjukkan pemakaian kontrasepsi hormonal lebih tinggi dibandingkan dengan kontrasepsi non hormonal. Berdasarkan hasil penelitian yang dilakukan oleh Abdullah pada tahun 2013 di Manado terhadap 42 responden diperoleh hasil bahwa adanya hubungan pemakaian kontrasepsi hormonal dengan kejadian kanker serviks. Kemungkinan terjadinya kanker serviks untuk ibu dengan pemakaian alat kontrasepsi hormonal adalah 0,18 kali dibandingkan dengan pemakaian kontrasepsi non hormonal. ${ }^{9,10}$

Berdasarkan uraian tersebut dapat diketahui bahwa kejadian kanker serviks jauh meningkat dari tahun 2014 sampai tahun 2015, hal tersebut seiring dengan meningkatnya perempuan yang melakukan seks pada usia muda, ibu-ibu yang memiliki paritas tinggi, jumlah akseptor KB. Oleh karena itu untuk mengetahui kebenarannya maka peneliti tertarik untuk melakukan penelitian mengenai "faktor-faktor yang berhubungan dengan kejadian kanker serviks di RSUP M.Djamil Padang tahun 2016".

\section{METODE PENELITIAN}

Jenis penelitian ini adalah deskriptif analitik dengan menggunakan pendekatan cross sectional. Penelitian ini dilaksanakan di ruangan ginekologi RSUP M.Djamil Padang pada bulan15 Desember 2016 - 15 Januari 2017.Sasaran penelitian ini adalah seluruh pasien yang dirawat di ruang ginekologi kebidanan pada tanggal 15 Desember 2016 - 15 Januari 2017 di RSUP M.Djamil Padang dengan teknik non random sampling. Analisis data menggunakan program yang ada pada komputer.

\section{HASIL}

\section{A. Hasil Analisis Univariat}

Tabel 1. Distribusi frekuensi responden penelitian

\begin{tabular}{lcc}
\hline \multicolumn{1}{c}{ Variabel } & f & (\%) \\
\hline Penderita & & \\
- Kanker Serviks & 30 & 37,5 \\
- Bukan Kanker Serviks & 50 & 62,5 \\
\hline Usia Pertama Melakukan & & \\
Intercourse & 48 & 60 \\
- Muda ( <20 tahun) & 32 & 40 \\
- Tidak Usia Muda ( $\geq 20$ tahun & & \\
\hline Paritas & 27 & 33,8 \\
- Tinggi ( > 3) & 53 & 66,2 \\
- Rendah ( $\leq 3)$ & & \\
\hline Pemakaian Kontrasepsi Hormonal & & \\
- Tidak Pernah & 35 & 43,8 \\
- 1 - < 5 tahun & 16 & 20 \\
- $\geq 5$ tahun & 29 & 36,2 \\
\hline
\end{tabular}

Berdasarkan tabel 1, dari 80 orang pasien, kurang dari separoh responden yang menderita kanker serviks $(37,5 \%)$,lebih dari separoh $(60 \%)$ pasien melakukan intercourse pada usia muda ( $<20$ tahun), kurang dari separoh $(33,8 \%)$ pasien memiliki paritas $>3$, kurang dari separoh $(36,2 \%)$ pasien memakai kontrasepsi hormonal dalam waktu $\geq$ 5 tahun. 


\section{B. Analisis Bivariat}

Tabel 2. Hasil analisis bivariat hubungan antara ,usia pertama melakukan intercourse, paritas dan pemakaian kontrasepsi hormonal dengan kejadian kanker serviks di ruangan ginekologi rsup dr m.djamil padang tahun 2017

\begin{tabular}{|c|c|c|c|c|c|}
\hline \multirow{3}{*}{ Variabel } & \multicolumn{4}{|c|}{ Kanker Serviks } & \multirow{3}{*}{$\begin{array}{c}p \\
\text { valu } \\
e\end{array}$} \\
\hline & \multicolumn{2}{|c|}{ Ya } & \multicolumn{2}{|c|}{ Tidak } & \\
\hline & $\mathbf{n}$ & $\%$ & $\mathbf{n}$ & $\%$ & \\
\hline \multicolumn{6}{|l|}{$\begin{array}{c}\text { Usia Pertama } \\
\text { Melakukan } \\
\text { intercourse }\end{array}$} \\
\hline $\begin{array}{l}\text { - Usia Muda ( }<20 \\
\text { tahun) }\end{array}$ & 18 & 56,2 & 14 & 43,8 & $\begin{array}{c}0,01 \\
0\end{array}$ \\
\hline $\begin{array}{l}\text { - Tidak Usia Muda ( } \\
\geq 20 \text { tahun) }\end{array}$ & 12 & 25 & 36 & 75 & \\
\hline \multicolumn{6}{|l|}{ Paritas } \\
\hline - Tinggi & 13 & 48,1 & 14 & 51,9 & 0,24 \\
\hline - Rendah & 17 & 32,1 & 36 & 67,9 & 6 \\
\hline \multicolumn{6}{|l|}{$\begin{array}{c}\text { Pemakaian alat } \\
\text { kontrasepsi } \\
\text { hormonal }\end{array}$} \\
\hline $\begin{array}{l}\text { - } \text { Tidak Pernah } \\
-\quad 1-<5 \text { tahun }\end{array}$ & $\begin{array}{l}8 \\
4\end{array}$ & $\begin{array}{c}22,9 \\
25\end{array}$ & $\begin{array}{l}27 \\
12\end{array}$ & $\begin{array}{c}77,1 \\
75\end{array}$ & $\begin{array}{c}0,00 \\
3\end{array}$ \\
\hline$-\quad \geq 5$ tahun & 18 & 62,1 & 11 & 37,9 & \\
\hline
\end{tabular}

Berdasarkan tabel 2 diketahui dari 32 orang pasien yang melakukan intercourse pada usia muda ( $<20$ tahun) sebanyak 18 orang $(56,2 \%)$ menderita kanker serviks, lebih banyak dari yang melakukan intercourse pada usia $\geq 20$ tahun yaitu sebanyak 12 orang $(36,4 \%)$. Terdapat hubungan usia pertama melakukan intercourse dengan kejadian kanker serviks ( $p$ 0,010). Diketahui dari 27 orang pasien yang memiliki paritas tinggi sebanyak 13 orang $(48,1 \%)$ menderita kanker serviks, lebih sedikit dari yang memiliki paritas rendah yaitu sebanyak 17 orang $(32,1 \%)$, Tidak terdapat hubungan paritas dengan kejadian kanker serviks ( $p$ 0,246). Diketahui dari 29 pasien yang memakai kontrasepsi hormonal dalam waktu $\geq 5$ tahun sebanyak 18 orang $(62,1 \%)$ menderita kanker serviks, lebih banyak dibandingkan yang tidak memakai kontrasepsi hormonal namun menderita kanker serviks yaitu sebanyak 8 orang $(22,9 \%)$.Terdapat hubungan pemakaian kontrasepsi hormonal dengan kejadian kanker serviks $(p 0,003)$.

\section{PEMBAHASAN}

\section{A. Analisis Univariat}

Berdasarkan tabel 1, dari 80 orang pasien, kurang dari separoh responden yang menderita kanker serviks (37,5\%), lebih dari separoh $(60 \%)$ pasien melakukan intercourse pada usia muda ( $<20$ tahun), Hal ini kemungkinan disebabkan karena lebih dari separoh pasien berpendidikan rendah $(52,5 \%)$, dimana pendidikan merupakan salah satu hal yang penting karena melalui pendidikan inilah pasien dapat memperoleh pengetahuan mengenai kesehatan reproduksi. Sehingga dengan adanya pengetahuan tentang kesehatan reproduksi tersebut menambah kesadaran pasien untuk tidak melakukan intercourse pada usia muda.
Berdasarkan tabel 1. Dari 80 orang pasien, kurang dari separoh $(33,8 \%$ )pasien memiliki paritas > 3. Kurang dari separoh $(36,2 \%)$ pasien memakai kontrasepsi hormonal dalam waktu $\geq 5$ tahun, Hal ini dipengaruhi oleh tingkat pendidikan pasien, dimana pada penelitian ini lebih banyak pasien berpendidikan rendah yaitu sebanyak $52,5 \%$. Pendidikan merupakan salah satu faktor yang dapat mempengaruhi seseorang dalam bersikap, sebagaimana menurut Notoatmojo pendidikan dapat mempengaruhi seseorang termasuk perilaku seseorang akan pola hidup terutama dalam memotivasi untuk sikap berperan serta dalam pembangunan.

Hasil penelitian ini hampir sama dengan penelitian yang dilakukan oleh Ridhaningsih (2010) di RSUD Dr.Moewardi Surakarta, terdapat kurang dari separoh responden yang menderita kanker leher rahim yaitu sebanyak $38 \%$ dan samasama menggunakan desain cross-sectional.

Hasil penelitian ini hampir sama dengan penelitian yang dilakukan oleh Setyarini tahun 2009 di Medan mengenai faktorfaktor yang mempengaruhi kejadian kanker leher rahim pada penderita yang datang berobat di RSUP H. Adam Malik, yakni lebih dari separoh responden yang menikah pertama kali pada usia $\leq 20$ tahun yaitu sebanyak $60 \%$ responden. Namun penelitian Setyarini memiliki perbedaan dengan yang peneliti lakukan, yaitu dari segi desain penelitian dan teknik pengambilan sampel. Desain penelitian yang peneliti gunakan yaitu cross-sectional dan teknik pengambilan sampel secara total populasi, sementara Setyarini menggunakan desain casecontrol dan teknik pengambilan sampel secara fixed disease sampling.

Penelitian yang peneliti lakukan hampir sama dengan penelitian yang dilakukan oleh Hidayat (2013) tentang hubungan kejadian kanker serviks dengan jumlah paritas di RSUD DR.Moewardi, yakni kurang dari separoh responden $(36,5 \%)$ memiliki paritas tinggi. Selain itu jumlah sampel pada penelitian yang dilakukan oleh Hidayat sebanyak 82 orang, hampir sama dengan jumlah sampel pada penelitian yang peneliti lakukan yaitu sebanyak 80 orang. Namun penelitian Hidayat memiliki perbedaan dengan yang peneliti lakukan dari segi desain penelitian dimana Hidayat menggunakan desain case-control, sedangkan peneliti menggunakan desain crosssectional.

Hasil penelitian ini hampir sama dengan penelitian yang dilakukan oleh Melva (2008) terdapat kurang dari separoh responden $37,5 \%$ tidak pernah menggunakan kontrasepsi hormonal. Selain itu penelitian oleh Melva menggunakan desain cross-sectional dan teknik pengambilan sampel secara total populasi, sama dengan desain dan teknik pengambilan sampel pada penelitian yang peneliti lakukan. Namun ada beberapa perbedaan antara penelitian Melva dengan penelitian yang peneliti lakukan dari segi hasil ukur. Melva mengelompokkan hasil ukur pada pemakaian kontrasepsi hormonal ke dalam 2 kelompok yaitu tidak pernah dan pernah, sedangkan peneliti mengelompokkan pemakaian kontrasepsi hormonal kedalam 3 kelompok yaitu tidak pernah, Tidak pernah, $1-<5$ tahun dan $\geq 5$ tahun.

Kanker serviks merupakan penyakit kanker pada perempuan yang disebabkan karena infeksi human Pappiloma Virus (hPV) yang merangsang perubahan perilaku sel epitel serviks. Kanker serviks biasanya terjadi pada perempuan usia subur yang ditularkan melalui hubungan seksual dan ditemukan pada $95 \%$ kasus kanker serviks (mulut rahim) dimana infeksi 
hPV dapat menetap menjadi displasia atau sembuh secara sempurna.

Faktor pemicu terjadinya kanker serviks yaitu memiliki pasangan seksual lebih dari satu, intercourse dimulai sejak usia muda, angka paritas lebih dari 4, kurangnya asupan zat gizi, imunosupresi, merokok dan paparan hormon steroid.Kanker serviks pada stadium dini sering tidak menunjukkan gejala, bahkan tidak menimbulkan gejala sama sekali. Gejala yang mungkin timbul yaitu nyeri pada waktu senggama, perdarahan sesudah senggam dan keluar keputihan atau cairan encer dari vagina.

Menurut para ahli intercourse yang efektif yaitu jika dilakukan ketika sudah menginjak usia 20 tahun, intercourse pada usia muda ( $<20$ tahun) dikatakan dapat menyebabkan kanker serviks karena pada usia tersebut perubahan sel dalam mulut rahim sedang dalam fase yang sangat aktif, ketika sel membelah secara aktif (metaplasi) tidak boleh ada kontak atau rangsangan apapun dari luar termasuk benda asing seperti alat kelamin laki-laki dan sel sperma. Masuknya benda asing tersebut menyebabkan perkembangan sel menjadi abnormal.

Paritas merupakan banyaknya kelahiran hidup yang dimiliki oleh seorang perempuan. Metode kontrasepsi hormonal merupakan salah satu metode kontrasepsi yang memiliki efektifitas tinggi, hormon yang terkandung di dalam kontrasepsi ini adalah hormon sintetik estrogen dan progesteron.Hormon estrogen berfungsi untuk stimulasi pertumbuhan dan perkembangan yaitu menyebabkan pertumbuhan baik ukuran maupun jumlah sel pada berbagai organ reproduksi wanita salah satunya di serviks uteri. Hormon progesteron mengadakan perubahan konsistensi pada serviks sehingga terjadi sumbatan lendir yang terbentuk di dalam serviks sehingga tidak dapat ditembus oleh sperma.

\section{B. Analisis Bivariat}

\section{Hubungan Usia Pertama Melakukan Intercourse dengan Kejadian Kanker Serviks di Ruangan Ginekologi RSUP DR M.Djamil Padang Tahun 2017}

Berdasarkan tabel 2 diketahui dari 32 orang pasien yang melakukan intercourse pada usia muda ( $<20$ tahun) sebanyak 18 orang $(56,2 \%)$ menderita kanker serviks, lebih banyak dari yang melakukan intercourse pada usia $\geq 20$ tahun yaitu sebanyak 12 orang $(36,4 \%)$. Sedangkan dari 48 pasien yang melakukan intercourse pada usia $\geq 20$ tahun sebanyak 36 orang (75\%) tidak menderita kanker serviks, lebih banyak dari yang melakukan intercourse pada usia $<20$ tahun yaitu sebanyak 14 orang ( 48,3\%). Pasien yang melakukan intercourse pada usia < 20 tahun cenderung menderita kanker serviks. Terdapat hubungan usia pertama melakukan intercourse dengan kejadian kanker serviks di ruangan ginekologi RSUP DR M.Djamil Padang tahun 2017 dengan $p$ value 0,010 .

Penelitian ini hampir sama dengan penelitian yang dilakukan oleh Melva, bahwa terdapat hubungan usia pertama melakukan hubungan seksual dengan kejadian kanker leher rahim $(p=0,000)$. Selain itu desain penelitian dan teknik pengambilan sampel yang digunakan pada penelitian Melva ini sama pada penelitian yang peneliti lakukan, yaitu menggunakan desain cross-sectional dan teknik pengambilan sampel secara total populasi. ${ }^{39}$
Penelitian yang dilakukan oleh Darmayanti (2015) juga mendapatkan hasil yang sama dengan yang peneliti lakukan, yaitu terdapat hubungan usia pertama melakukan hubungan seksual dengan kejadian kanker serviks $(p=0,001)$. Desain penelitian yang digunakan juga sama pada penelitian yang peneliti lakukan, yaitu menggunakan desain cross-setional. Tidak hanya memiliki persamaan, penelitian Darmayanti ini juga memiliki perbedaan dengan penelitian peneliti dari teknik pengambilan sampel dan analisis yang digunakan. Darmayanti menggunakan teknik pengambilan sampel dengan teknik accidental sampling dan menggunakan analisis multivariat. Hasil dari analisis multivariat menunjukkan bahwa dari 3 variabel, faktor usia pertama melakukan hubungan seksual yang memiliki hubungan yang bermakna. ${ }^{40}$

SDKI 2012 mengumpulkan informasi mengenai waktu pertama kali melakukan hubungan seksual untuk semua pria dan wanita kawin yang menunjukkan bahwa wanita yang lebih tua cenderung melakukan hubungan seksual pada umur lebih muda dibandingkan dengan wanita yang lebih muda. dari 30 orang responden terdapat 20 orang responden yang menderita kanker serviks yang melakukan hubungan seksual pada usia di atas < 20 tahun. ${ }^{21}$

Menurut para ahli intercourse yang efektif yaitu jika dilakukan ketika sudah menginjak usia 20 tahun dan itu pun harus dalam ikatan pernikahan yang resmi. Saat ini kanker serviks merupakan penyakit yang ditakuti oleh setiap perempuan dan kini akan mengancam para gadis di bawah umur yang melakukan intercourse. Intercourse pada usia muda $(<20$ tahun) dikatakan dapat menyebabkan kanker serviks karena pada usia tersebut perubahan sel dalam mulut rahim sedang dalam fase yang sangat aktif, ketika sel membelah secara aktif (metaplasi) tidak boleh ada kontak atau rangsangan apapun dari luar termasuk benda asing seperti alat kelamin laki-laki dan sel sperma. Masuknya benda asing tersebut menyebabkan perkembangan sel menjadi abnormal. ${ }^{22}$

Dari hasil analisa yang dilakukan terdapat hubungan usia pertama melakukan intercourse dengan kejadian kanker serviks. Hal ini bisa dicegah dengan tidak melakukan seks bebas dan bagi perempuan menikah pada usia minimal 21 tahun sesuai dengan usia ideal perempuan menikah yang ditetapkan oleh BKKBN.

Selain itu perlunya peran pemerintah agar lebih gencar dalam memberdayakan perempuan dengan mendirikan pelatihan-pelatihan keterampilan kepada perempuan sehingga para perempuan tersebut memiliki keahlian untuk bekerja secara mandiri dan mempunyai penghasilan sendiri. Selain itu pemerintah diharapkan membuat program yang dapat menambah pengetahuan masyarakat mengenai kesehatan reproduksi yang dibantu oleh TOMA dan aparat pemeritah lainnya dalam menjalankan program tersebut. Selain itu adanya peran keluarga diharapkan bisa menyokong program pemerintah, sehingga berkurangnya perempuan yang menikah dini.

\section{a. Hubungan Paritas dengan Kejadian Kanker Serviks di Ruangan Ginekologi RSUP DR M.Djamil Padang Tahun 2017}

Berdasarkan tabel 2 diketahui dari 27 orang pasien yang memiliki paritas tinggi sebanyak 13 orang $(48,1 \%)$ menderita kanker serviks, lebih sedikit dari yang memiliki paritas rendah yaitu sebanyak 17 orang $(32,1 \%)$. Sedangkan dari 53 orang pasien yang memiliki paritas rendah sebanyak 36 orang 
$(67,9 \%)$ tidak menderita kanker, lebih banyak dari yang memiliki paritas tinggi yaitu sebanyak 14 orang $(51,9 \%)$. Tidak terdapat hubungan paritas dengan kejadian kanker serviks di ruangan ginekologi RSUP M.Jamil Padang tahun 2017 dengan $p$ value 0.246 .

Penelitian ini hampir sama dengan penelitian yang dilakukan oleh Fitri (2009) tentang faktor-faktor yang mempengaruhi kejadian kanker serviks di Puskesmas Karanganyar, hasil penelitiannya menunjukkan tidak ada hubungan paritas dengan kejadian kanker serviks. Desain penelitian yang digunakan oleh Fitri sama dengan desain penelitian yang peneliti gunakan, yaitu menggunakan desain cross-sectional. Perbedaan penelitian Fitri dengan yang peneliti lakukan yaitu dari teknik pengambilan sampel, dimana penelitian fitri menggunakan teknik purpossive sampling sedangkan peneliti menggunakan tekni total sampling. ${ }^{41}$

Perempuan yang memiliki 3 atau lebih kehamilan mempunyai peningkatan risiko terkena kanker serviks. Penelitian juga telah menunjukkan bahwa perubahan hormon selama kehamilan sebagai kemungkinan yang menyebabkan perempuan lebih rentan terhadap infeksi HPV atau pertumbuhan kanker. Pendapat lain mengatakan bahwa trauma servikal yang terjadi saat melahirkan dapat menyebabkan virus HPV masuk dan berubah menjadi kanker. ${ }^{12}$

Hasil penelitian ini menunjukkan tidak ada hubungan paritas dengan kejadian kanker serviks. Hal ini kemungkinan disebabkan oleh jumlah pasien yang menderita kanker serviks yang memiliki paritas tinggi $(48,1 \%)$ lebih sedikit dibandingkan dengan yang tidak menderita kanker serviks $(51,9 \%)$.

\section{b. Hubungan Pemakaian Kontrasepsi Hormonal dengan Kejadian Kanker Serviks di Ruangan Ginekologi RSUP DR M.Djamil Padang Tahun 2017}

Berdasarkan tabel 2 diketahui dari 29 pasien yang memakai kontrasepsi hormonal dalam waktu $\geq 5$ tahun sebanyak 18 orang $(62,1 \%)$ menderita kanker serviks, lebih banyak dibandingkan yang tidak memakai kontrasepsi hormonal namun menderita kanker serviks yaitu sebanyak 8 orang $(22,9 \%)$. Pasien dengan riwayat pemakaian kontrasepsi hormonal dalam waktu $\geq 5$ tahun cenderung menderita kanker serviks. Terdapat hubungan pemakaian kontrasepsi hormonal dengan kejadian kanker serviks di ruangan ginekologi RSUP DR M.Djamil Padang tahun 2017 dengan $p$ value 0.003.

Hasil penelitian ini hampir sama dengan penelitian yang dilakukan oleh Darmayanti (2015), terdapat hubungan pemakaian kontrasepsi hormonal dengan kanker leher rahim $(p=0,000)$. Selain itu, desain penelitian yang digunakan pada penelitian Darmayanti sama dengan yang peneliti gunakan yaitu menggunakan desain cross-sectional. Namun terdapat perbedaan pada teknik pengambilan sampel yang digunakan oleh Darmayanti dan yang peneliti lakukan, Darmayanti menggunakan teknik accidental sampling sedangkan peneliti menggunakan teknik total populasi.

Secara teoritis mekanisme yang mungkin berperan yaitu perubahan dalam lendir serviks yang dapat menambah kerentanan jaringan, perubahan dari respon imun yang menambah kerentanan terhadap infeksi virus, defisiensi folat di dalam serviks sehingga dapat merangsang perkembangan lesi serviks yang abnormal. ${ }^{16}$

Hormon estrogen berfungsi merangsang pertumbuhan sel yang cenderung mendorong terjadinya penyakit kanker, sedangkan hormon progesteron melindungi terjadinya pertumbuhan sel yang berlebihan dalam tubuh. Ada kecenderungan bahwa seseorang yang berlebihan hormon estrogen dan kekurangan hormon progesteron menyebabkan meningkatnya risiko kanker payudara, kanker leher rahim, kanker rahim dan kanker prostat dari buah zakar pria. ${ }^{15}$ Salah satu keterbatasan kontrasepsi progestin yaitu pada penggunaan jangka panjang dapat menimbulkan kekeringan pada vagina, berkurangnya cairan vagina menyebabkan iritasi dan rasa nyeri saat berhubungan intim yang menyebabkan infeksi pada vagina lebih rentan terjadi. ${ }^{17,18}$

Hasil analisis menunjukkan adanya hubungan pemakaian kontrasepsi hormonal dengan kejadian kanker serviks, hal ini berkaitan dengan lamanya penggunaan kontrasepsi hormonal yang menyebabkan peningkatan hormon progesteron dan estrogen dalam tubuh yang menjadi salah satu faktor risiko terjadinya kanker serviks. Pada umumnya responden lebih banyak menggunakan kontrasepsi hormonal dibandingkan kontrasepsi non hormonal seperti kontrasepsi pil, suntik dan implan, hal ini terlihat dari jawaban yang diberikan responden pada saat melakukan wawancara.

\section{SIMPULAN DAN SARAN}

\section{A. SIMPULAN}

Berdasarkan hasil penelitian yang dilakukan mengenai faktor-faktor yang berhubungan dengan kejadian kanker serviks di ruangan Ginekologi RSUP DR M.Djamil Padang Tahun 2017 dengan sampel sebanyak 80 orang, dapat diperoleh kesimpulan sebagai berikut :

1. Kurang dari separoh $(37,5 \%)$ pasien menderita kanker serviks di ruangan ginekologi RSUP DR M.Djamil Padang tahun 2017

2. Lebih dari separoh $(60 \%)$ pasien melakukan intercourse pada usia muda $(<20$ tahun) di ruangan ginekologi RSUP DR M.Djamil Padang tahun 2017

3. Kurang dari separoh (33,8\%)pasien memiliki paritas $>3$ di ruangan ginekologi RSUP DR M.Djamil Padang tahun 2017

4. Kurang dari separoh $(36,2 \%)$ pasien memakai kontrasepsi hormonal dalam waktu $\geq 5$ tahun di ruangan ginekologi RSUP DR M.Djamil Padang tahun 2017

5. Terdapat hubungan usia pertama melakukan intercourse dengan kejadian kanker servik di ruangan Ginekologi RSUP DR M.Djamil Padang Tahun 2017.

6. Tidak terdapat hubungan paritas dengan kejadian kanker servik di ruangan Ginekologi RSUP DR M.Djamil Padang Tahun 2017.

7. Terdapat hubungan pemakaian kontrasepsi hormonal dengan kejadian kanker serviks di ruangan Ginekologi RSUP DR M.Djamil Padang Tahun 2017.

\section{B. SARAN}

\section{Kepada Instansi Kesehatan}

Diharapkan hasil penelitian ini dapat menjadi gambaran bagi instansi kesehatan untuk mengoptimalkan pelaksanaan IVA Tes sebagai deteksi dini kanker serviks sehingga 
penanganannya pun juga akan lebih cepat dan lebih baik.

2. Kepada Institusi Pendidikan

Diharapkan penelitian ini bisa menjadi referensi dan tambahan kepustakaan bagi Poltekkes Kemenkes Padang terutama jurusan kebidanan.

3. Kepada Peneliti Lain

Diharapkan skripsi ini dapat dijadikan sebagai data pembanding untuk melanjutkan penelitian selanjutnya agar melakukan penelitian lebih mendalam tentang kejadian kanker servik dengan menggunakan variabel independen lain yang belum diteliti seperti memiliki pasangan lebih dari satu, kurangnya asupan gizi, merokok dan lainlain dengan desain penelitian berupa case-control agar didapatkan hasil yang lebih baik. Bisa juga menggunakan variabel yang sama dengan yang peneliti lakukan seperti variabel kontrasepsi hormonal mengenai jenis kontrasepsi hormonal yang digunakan dengan lama pemakaiannya.

\section{DAFTAR PUSTAKA}

Buletin kanker. Situasi Penyakit Kanker. Jakarta : Kementerian Kesehatan RI; 2015

Prawirohardjo S. Ilmu Kebidanan.Edisi Ke-3. Jakarta: PT Bina Pustaka Sarwono Prawirohardjo; 2011

Kementerian Kesehatan RI. Profil Kesehatan Indonesia 2014. Jakarta: kementerian Kesehatan RI; 2015

RSUP M.Djamil Padang. Buku Register Ginekologi Ruang Kebidanan. Padang: januari 2014- desember 2015

Persik LB. Hubungan Penggunaan Kontrasepsi Hormonal Dengan Kejadian Lesi Prakanker Serviks [Skripsi]. Padang: Universitas Andalas; 2016

Kumalasari I. Kesehatan Reproduksi. Jakarta: Salemba Medika; 2012

Vesco KK. Risk factors and other epidemiologic considerations for cervical cancer screening. NCBI; 2011 Tersedia dari :http://www.ncbi.nlm.nih.gov/pubmed/22006929

Hidayat E, Hasibuan DHS, Fitriyati Y. Hubungan Kejadian Kanker Serviks dengan Jumlah Paritas di RSUD Dr.Moewardi tahun 2013 [Skripsi]. Fakultas Kedokteran Universitas Islam Indonesia [Sumber Online].September-Desember 2014

Dinas Kesehatan Provinsi Sumatera Barat. Profil Kesehatan 2014. Padang: Dinas Kesehatan Provinsi Sumatera Barat; 2014

Abdullah S, Bawotong J, Hamel R. HubunganPemakaian Kontrasepsi Hormonal Dan Non Hormonal Dengan Kejadian Kanker Serviks Di Ruang D Atas Blue Prof. Dr. R.D.Kandow Manado. E-Journal Keperawatan [Sumber Online] agustus 2013; 1(1): 1 - 7

Sastrosudarmo Wh. Kanker The Sillen Killer. Jakarta: Garda Media; 2012

American Cancer Society. Cervical Cancer Prevention And Early Detection. America: American Cancer Society; 2014

Setiati E. Waspadai 4 Kanker Ganas Pembunuh Wanita. Yogyakarta: ANDI; 2009
Cancer Research UK. How Being Overweight Causes Cancer. Inggris: Cancer Research; 2016

Mulyani N, Rinawati M. Kanker Payudara Dan IMS PadaKehamilan. Yogyakartaa: Nuha Medika; 2013

Hartanto H. Keluarga Berencana Dan Kontrasepsi. Jakarta: Pustaka Sinar Harapan; 2010

Affandi B. Buku Panduan Praktis Pelayanan Kontrasepsi/Editor. Jakarta: PT Bina Pustaka Sarwono Prawirohardjo; 2013

Sulistyawati E, Proverawati A. Menopause dan Sindrome Premenopause. Yogyakarta: Nuha Medika; 2010

Purwoastuti E, Elisabeth SW. Panduan Materi Kesehatan Reproduksi Dan Keluarga Berencana. Yogyakarta: Pustaka Baru Press; 2015

Nugroho AW, Santoso N, penyunting. Ilmu Gizi Menjadi Sangat Mudah. Edisi ke-2. Jakarta: EGC; 2011

Badan Pusat Statistik. Survei Demografi dan Kesehatan Indonesia 2012. Jakarta: kementerian kesehatan RI; 2012

Mangenre I.Awas, Ini Bahayanya Jika Perempuan Hubungan Seks Sebelum Usia 17 Tahun. Makassar. Tribunnnews.com

Direktorat Teknologi Informasi dan Dokumentasi. Kamus Istilah Kependudukan dan Keluarga Berencana. Jakarta: BKKBN; 2006

Bagian obstetri dan gynekologi. Obstetri Fisiologi. Bandung: FK UNPAD

Mayrita SN, Handayani N. Hubungan Antara Paritas Dengan Kejadian Kanker Serviks Di Yayasan Kanker Wisnuwardhana Surabaya. Surabaya: UNUSA; 2014

Handayani I. Buku Ajar Pelayanan Keluarga Berencana. Yogyakarta: Rihama; 2011

Maryunani A. Biologi Reproduksi Dalam Kebidanan. Jakarta: TIM; 2010

Paramita S. High parity and hormonal contraception use as risk factors for cervical cancer in East Kalimantan. Laboratory of Public Health [Sumber Online] November 2010; 19(4)

Manuaba IAC. Ilmu Kebidanan Penyakit Kandungan dan Keluarga Berencana untuk Pendidikan Bidan. Edisi Ke-2. Jakarta: EGC; 2010

Widiarti D, Komalasari R, penyunting. Buku Ajar Kesehatan Reproduksi Wanita. Edisi Ke-2. Jakarta: ECG; 2009

BKKBN. Susuk KB. Jatim: BKKBN; 2015

Riyanto A. Aplikasi Metodologi Penelitian Kesehatan. Yogyakarta: Nuha Medika; 2011

Notoatmodjo S. Metodologi Penelitian Kesehatan. Jakarta: Rineka Cipta; 2012

Hastono SP, Sabri L. Statistik Kesehatan. Jakarta: PT Rajagrafindo Persada; 2011

Sujarweni VW. Statistik Untuk Kesehatan. Yogyakarta: Gava Media; 2015

Ridhaningsih. Hubungan Aktivitas Seksual Pada Usia Dini, Promiskuitas Dan Bilas Vagina Dengan Kejadian Kanker Leher Rahim Pada Pasien Onkology di RSUD Dr.Moewardi Surakarta. Jurnal Fakultas Kesehatan Masyarakat [sumber online]. Juni 2011 [diakses 16 februari 2017]; 5(2):162-232. Tersedia dari: URL :

http://journal.uad.ac.id/index.php/KesMas/article/view/ $\underline{1077}$ 
Setyarini E. Faktor-Faktor Yang Berhubungan Dengan Kejadian Kanker Leher Rahim di RSUD DR. Moewardi Surakarta. JurnalUniversitas Muhammadiyah Surakarta [sumber online]. 2009 [diakses 16 februari 2017]. Tersedia dari: URL: http://eprints.ums.ac.id/3942/1/J410040010.pdf

Notoatmojo S. Pendidikan dan Perilaku Kesehatan. Jakarta. Rineka cipta. 2003

Melva. Faktor-Faktor Yang Mempengaruhi Kejadian Kanker Leher Rahim Pada Penderita Yang Datang Berobat di RSUP H.Adam Malik Medan Tahun 2008. Jurnal USU [sumber online]. 2008 [diakses 16 februari 2017]. Teredia dari: URL:

http://repository.usu.ac.id/bitstream/123456789/6778/1 109E00801.pdf

Darmayanti. Faktor-Faktor Yang Berhubungan Dengan Kanker Leher Rahim di RSUD Ulin Bnajarmasin. Jurnal KesehatanPoltekkes Tanjung Karang [sumber online] 2015 [diakses 16 februari 2017]; 6(2): 172-177. Tersedia dari: URL:

http://ejurnal.poltekkestjk.ac.id/index.php/JK/article/vi ew/102/92

Rohani F. Faktor-Faktor Yang Mempengaruhi Kejadian Kanker Serviks di Puskesmas Karanganyar. Jurnal Ilmiah Kesehatan Keperawatan [sumber online] Maret 2012 [diakses 16 februari 2017]; 5(2): 109-118. Tersedia dari: URL http://id.portalgaruda.org/index.php?ref=browse\&mod =viewarticle \&article $=65814$ 